\title{
Effect of sanitary measures on performance of broiler chickens in Marathwada region of Maharashtra, India
}

\author{
P.G.Pardeshi, A.N.Kulkarni, R.S.Mule, S.P. Poul*, S.V. Baswade \\ Department of Animal Husbandry and Dairy science \\ College of Agriculture, Marathwada Agricultural University, Parbhani-431 402. (M.S.) India. \\ * Corresponding author email: poul_s@rediffmail.com \\ Received: 19-11-2010 Accepted: 28-12-2010, Published Online: 04-06-2011 \\ doi: $10.5455 /$ vetworld.2011.371-373
}

\begin{abstract}
Fifteen broiler farms in Marathwada region of Maharashtra state were selected and effect of sanitary measures on performance of broiler chickens was studied by on the spot observation and on the basis of questionnaire. All the farms categorized under excellent, optimum and poor sanitation farm on the basis of sanitary measures adopted on the farm. It was evident that the sanitary measures had direct effect on the performance of broiler chickens. The mortality rate and feed conversion ratio was highest in poor sanitation broiler farms followed by optimum and excellent sanitation broiler farms. The weight gain per bird at 45 days age was highest in excellent sanitation farms followed by optimum and poor sanitation farms.
\end{abstract}

Key words: Broiler farm, Marathwada, Sanitary measures, Mortality rate, Feed conversion ratio, Weight gain per bird.

\section{Introduction}

Poultry sector, beside employment generation and subsidiary income increase, provides nutritional security especially to the rural poor. The value of output from poultry sector is nearly 15000 crore and provide direct or indirect employment to over 2 million people. About 25 per cent of total egg production in the country comes from desi poultry, which is unorganized rural backyard system (Anonymous, 2006). The desire to obtain maximum weight gain in minimum time and attempts to increase the number of crops in a year forces the farmers to compromise on sanitation of broiler farms.

A common concern of poultry industry is presence of bacterial and fungal pathogens i.e. disease and infections in bird's environment. A high population of pathogenic bacteria in the poultry house contributes to a decline in wellness of flock and increased levels of pathogens recoverable carcass entering the consumer market (Payne et al., 2005).

Aim of every broiler farmer is to run farm successfully and economically viable and to gain the confidence of market or consumers without compromising quality of final product and to sustain in population. One of key preventive measure for poultry disease is proper sanitation. Poultry house sanitation plays a crucial role in control and prevention of harmful diseases (Watkins et al, 1999).
Emphasis needs to be given to safety and security of poultry flocks from different health hazards due to improper management and health cover which has a direct bearing on poultry industry and indirect bearing not only on economy of farmers but also on national economy.

A good sanitation programme can benefit the grower by optimizing bird performance while lowering the incidence of commercial flocks. Good sanitation can be difference between a profitable and unprofitable operation. The lacunae in managemental procedures need to be identified by on the spot survey report. Keeping these facts in views the present study is planned in Marathwada region of Maharashtra state for assessment of sanitary measures adopted by broiler farms.

\section{Materials and Methods}

Fifteen broiler farms in Marathwada region of Maharashtra state were selected for present study (Table 1). Assessment of sanitary measures of broiler farms on the basis of on the spot observation by questionnaire was done as per score system. The questionnaire filled in by supervisors consisted of exhaustive list of sanitary measures expected to be adopted by the broiler farmers for effective sanitation. The observations in the questionnaire were authenticated by on spot observation. The factors considered in 
Table 1. Broiler farms of Marathwada region selected for the study.

\begin{tabular}{clc}
\hline Alphabetic designation & Name of poultry farm & District \\
\hline A & Sagar poultry farm & Jalna \\
B & Rahul poultry farm & Aurangabad \\
C & Sandeep poultry farm & Parbhani \\
D & Mansi poultry farm & Aurangabad \\
E & Thorat poultry farm & Beed \\
F & Kamal poultry farm & Latur \\
G & Usman poultry farm & Jalna \\
H & Unique poultry farm & Aurangabad \\
I & Jaihind poultry farm & Latur \\
J & Radhika poultry farm & Parbhani \\
L & Balaji poultry farm & Beed \\
M & Savan poultry farm & Aurangabad \\
N & Rajendra poultry farm & Aurngabad \\
O & Vatan poultry farm & Osmanabad \\
\end{tabular}

Table 2. Points allotted on the spot observation of broiler farm.

\begin{tabular}{llc}
\hline Sr.No. & Parameters & Maximum weightage \\
\hline 1 & Cleanliness in premises. & 7 \\
2 & Disinfection of shed. & 7 \\
3 & Dry cleaning and burning. & 6 \\
4 & Wet cleaning. & 6 \\
5 & White wash to shed. & 7 \\
6 & Disinfectants used in white wash. & 6 \\
7 & Fumigations of shed & 7 \\
8 & Foot bath system. & 6 \\
9 & Sanitation of drinking water. & 7 \\
10 & Disinfection of water channels and waterers. & 7 \\
11 & Cleaning of water system. & 6 \\
12 & Disinfection of feeder during rest period. & 7 \\
13 & Disposal method of dead birds and its distance from broiler house. & 7 \\
14 & Raking of litter & 7 \\
15 & Ventilation & 7 \\
\end{tabular}

questionnaire and points allotted is presented in Table 2 .

The farms having total score more than 75 per cent in each of the above parameters (1 to 15$)$ were graded as 'Excellent sanitation', those score between 75-50 percent in each parameter were rated as 'optimum sanitation' and those having score less than 50 percent in each parameter were rated as 'poor sanitation'. Data pertaining to weight gain, FCR and feed intake per batch of broiler was collected during the survey. The data collected on the performance of broilers was tabulated and statistically analyzed by Completely Randomized Block Design (Panse and Sukhatme, 1967).

\section{Results and Discussion}

For classification of broiler farms on the basis of sanitary measures, information on the basis of questionnaire was collected. The factors considered in questionnaire and points allotted were presented in Table 2. For study the effect of the sanitary measure on performance of the broilers, the data of feed conversion ratio, weight gain and mortality percentage on individual farm was collected and tabulated.

Mortality performance in broiler: Data regarding mortality in broiler collected at age of 45 days during the present study (Table 3 ). The percent mortality was highest (14.00) in poor sanitation farms followed by optimum (9.86) and excellent sanitation farms (5.60). The cause of mortality in each of farm is different. Farooqui et al. (2002) also found overall mortalities were higher in poor sanitary condition as compared to excellent sanitation.

Weight gain of broiler: During the study data collected pertaining to per bird weight gain in broilers of excellent, optimum and poor sanitation broiler farms (Table 4). For calculating the per bird weight gain the actual number of birds available on completion of 45 days of age and their cumulative weight was taken into consideration. The mean weight gains of the broiler at the age of 45 days in excellent, 
Table 3. Mortality rate and its probable cause in the three categories of broiler farm.

\begin{tabular}{lll}
\hline FarmMortality mean & $\mathbf{( \% )}$ & Probable causes \\
\hline Excellent sanitary broiler farms & 5.60 & Tampering of birds, Physical injuries, Suffocation. \\
Optimum sanitary broiler farms & 9.86 & $\begin{array}{l}\text { Tampering of birds, Physical injuries, Disease like Cocciodices and } \\
\text { Raniket. }\end{array}$ \\
Poor sanitary broiler farms & 14.00 & $\begin{array}{l}\text { Tampering of birds, Suffocation, Physical injuries, Disease like } \\
\text { Cocciodices and Raniket. }\end{array}$ \\
\hline
\end{tabular}

Table 4. Comparison of weight gain of the three categories of broiler farm.

\begin{tabular}{lccc}
\hline Sr.No. & Excellent sanitary broiler farms $\mathbf{( k g )}$ & Optimum sanitary broiler farms $\mathbf{( k g )}$ & Poor sanitary broiler farms (kg) \\
\hline 1 & 2.00 & 1.50 & 1.25 \\
2 & 2.10 & 1.45 & 1.10 \\
3 & 1.90 & 1.65 & 1.25 \\
4 & 2.15 & 1.50 & 1.40 \\
5 & -- & 1.70 & 1.50 \\
6 & -- & 1.56 & -- \\
Mean & 2.037 & 1.575 & 1.300 \\
SE + & 0.0554 & 0.0423 & 0.0689 \\
C.D. $5 \%$ & 0.157 & 0.1173 & 0.1910 \\
\hline
\end{tabular}

Table 5. Comparison of feed conversion ratio of the three categories of broiler farm.

\begin{tabular}{lccc}
\hline Sr.No. & Excellent sanitary broiler farms $\mathbf{( k g )}$ & Optimum sanitary broiler farms $\mathbf{( k g )}$ & Poor sanitary broiler farms $(\mathbf{k g})$ \\
\hline 1 & 1.90 & 2.50 & 3.00 \\
2 & 1.85 & 2.45 & 3.20 \\
3 & 1.870 & 2.30 & 3.20 \\
4 & 1.87 & 2.75 & 3.10 \\
5 & -- & 2.65 & 3.33 \\
6 & -- & 2.40 & -- \\
Mean & 1.8556 & 2.5083 & 3.1600 \\
SE + & 0.0210 & 0.0676 & 0.0553 \\
C.D. $\%$ & 0.0583 & 0.1874 & 0.1532 \\
\hline
\end{tabular}

optimum and poor sanitation farms were $2.037,1.575$ and $1.300 \mathrm{~kg}$ respectively. It was evident from the data that productivity was highest in excellent sanitation broiler farm followed by optimum and poor sanitation broiler farms.

Feed conversion ratio of broiler: Assessment of feed converion ratio is one of most important factor for determining the performance of broilers. The data of feed conversion ratio in three groups of farms were collected at the age of 45 days during study. The mean feed conversation ration was highest (3.16) in poor sanitation farm, followed by optimum sanitation farm (2.50) and excellent sanitation farm (1.85). The comparison between mean feed conversion ratio of excellent, optimum and poor sanitation were statistically significant.

\section{Acknowledgements}

The authors are thankful to The Head, Department of Animal Husbandry and Dairy Science, Marathwada Agricultural University, Parbhani (M.S.) for providing the facilities and guidance required for conducting the research work.

\section{References}

1. Anonymous, (2006). Agriculture, India-2006. Publication Division, Ministry of Information and Broadcasting, Government of India., New Delhi. P-92.

2. Farooqui, A.R., S.A. Khan, Mahammad-Naeem and Hameed-Ahmed (1997). Effect of four commercially available disinfectants on growth traits and proximate analysis of meat of broiler chickens. Pak. Vet. J., 17(3) : 146148.

3. Panse, V.G. and Sukhatme, P.V. (1967). Statistical methods for agricultural workers, ICAR publication, New Delhi.

4. Payne, J.B., E.C. Kroger and S.E. Watkins (2005). Evaluation of disinfectant efficacy when applied to the floor of poultry grow out facilities. J. Appl. Poult. Res., 14:322-329.

5. Watkins, S.E., J.B. Payne and A.L. Walroup (1999). The bioburner : A new tool in poultry sanitation. UACES: AR Agriculture Newsletter : Avian Advice Newsletter. 